\title{
Sciendo
}

Administration, vol. 67, no. 1 (2019), pp. 73-83

doi: 10.2478/admin-2019-0009

\section{Towards greater collective impact: Developing the collaborative capability of the local community development committees (LCDCs)}

\author{
Rob Worrall \& Fergal O'Leary \\ Institute of Public Administration, Ireland
}

\section{Introduction}

Increasingly, there is a recognition that the global challenges of the twenty-first century necessitate a localised response to reflect the specific socio-economic and demographic circumstances of each locality (Nijkamp \& Kourtit, 2013). Moreover, when responding to 'wicked problems' (Crowley \& Head, 2017), it is recognised that no one partner has all the knowledge, information, expertise, resources or, in one sense, a unique mandate to tackle major issues; consequently, there is a need for organisations to work together at the local level across organisational, professional, psychological and political boundaries (Bryson et al., 2015; Worrall, 2015). The significance of collaboration for innovation as an effective means to enable long-term social and economic growth is recognised in the EU strategy Europe 2020, which seeks to secure a sustainable future (European Commission, 2010). In practical terms, this means that each locality should take an interdisciplinary approach to addressing development challenges, involving all organisations - public, private and not-for-profit - 
in finding innovative approaches to achieving sustainable economic and social development (Kozuch \& Sienkiewicz-Malyjurek, 2013).

In the Irish context, from the 1990s onwards, a series of structural reforms sought to formalise working relationships between local government, local development organisations and wider civil society (Department of Rural and Community Development, 2015; Shannon, 2018). In the latest manifestation of these arrangements, the local community development committees (LCDCs) take an intersectoral approach 'to bring a more integrated approach to local and community development' (Government of Ireland, 2017, p. 28), and are seen in Our Public Service 2020, the overall strategy for 'Development and Innovation in the public service', as the 'primary vehicle for collaboration for national public service providers at local level' (Government of Ireland, 2017, p. 26). The LCDCs bring together local government, civil society (including the community, voluntary and social inclusion sectors, local development bodies and trade unions), state agencies (such as the Health Service Executive, education and training boards and the Department of Employment Affairs \& Social Protection) and the private sector (business and farming representatives). Within this 'local forum where strategic, multi-agency approaches are implemented', local economic and community plans (LECPs) are 'used by LCDCs to facilitate a more joined-up approach' to ensure 'co-ordinated responses to locally agreed priorities' (Government of Ireland, 2017, p. 28). The LCDCs have a statutory mandate to oversee the coordination and management of local funding, including EU-supported, communityled local development funding from 2020 to 2027.

However, whilst we routinely hear a clarion call from policymakers for increased collaboration as the collective road to be taken, in reality, achieving collective impact (Kania \& Kramer, 2011) has often proven elusive (Worrall, 2014, 2015). The tangible hardware of processes - governance principles and frameworks, performance management frameworks, rules and regulations - are undoubtedly important, but are not of themselves sufficient to ensure a successful collaborative endeavour (Worrall \& Kjaerulf, 2017). Successful local development requires a greater focus on developing local collective leadership (Worrall, 2014, 2015), starting with the intangible 'software' of relationship-building to create a better understanding between local actors, and encourage a more open and adaptive mindset (Worrall \& Kjaerulf, 2018b). 
Thus, this article provides a brief overview of the experience and outcomes from a one-day pilot workshop, which sought to build the collaborative capability of LCDC members. Firstly, the practical challenges faced by the LCDCs will be considered, alongside an overview of how the literature suggests that these issues can be addressed. Secondly, the design, delivery and outcomes of the workshop are presented. And finally, the conclusion will reflect on potential implications and directions for future practice-based work in this field.

\section{Theoretical perspectives}

Within the context of the LCDCs, the historically embedded tensions which characterise relations between local government, community development and local (community) development organisations around roles, responsibilities and mandates have been well documented (for example, see Azzopardi, 2014; Callanan, 2018; Forde, 2005; Forde et al., 2015). Firstly, there seems to be an underlying conflict between passive representative democracy and active participatory democracy, with the dominance of the former, according to Forde et al. (2015), being perceived as leading to the power of decision-making gradually shifting into the hands of unelected managers. Indeed, antecedents of this tension date back to the foundation of the community district boards in the 1890s, where community-based activists were commonly perceived as a threat to the power and influence of local nationalist party politicians (Harvey, 2015).

In addition, the top-down nature of successive rounds of reform, involving the streamlining and merging of local development and community development structures, has been seen to have increased the perception of the dominance of local government (Azzopardi, 2015). Thirdly, Lloyd (2016) has also argued that a more individualist and consumerist approach, a marketisation of the state, has been to the detriment of the interests of socially disadvantaged groups (Lloyd, 2016), where managerial and elected members take precedence over other stakeholders (Sullivan, 2001). The top-down 'contractualism', with an emphasis on consumer needs and service quality, is also seen as being 'incompatible with the developmental, experimental and organic processes' of community development (Community Workers' Co-operative, 2003, cited in Forde, 2005, p. 145). Finally, whilst the public sector witnessed major funding reductions, from some quarters 
there is the perception that cuts experienced by the community and voluntary sector were proportionately greater, which Powell (2015, p. 4) claims is 'part of the process of deconstructing the welfare state in the era of globalisation'.

Within the local economic development literature, the significance of effective leadership for ensuring sustainable socio-economic improvements is increasingly recognised (OECD, 2013). Moreover, the need for leaders to recognise and respond to the strengths and development needs of differing localities has been recognised in the term 'place shaping' (Lyons, 2007), or leadership of place (Office for Public Management, 2009), where there is a shared responsibility to improve outcomes for the common good. This approach can be traced back to research on civic and place-based collaborative leadership, which developed in the US, particularly since the 1990s (Chrislip \& Larson, 1994; Chrislip, 2002), and on public integrative leadership (Crosby \& Bryson, 2005, 2010a, 2010b).

Whilst the "concept of leadership of place is still in its infancy, and can be used by different organizations to mean slightly different things' (Worrall, 2014, p. 3), it can be broadly summarised as 'all leadership activity that serves a public purpose in a given locality' (Hambleton, 2009, p. 6). This also infers that local public leadership (as opposed to public service leadership) 'is not solely about publicoffice holders but about those who shape public debate and action' (Hartley, 2018, pp. 203-4). This notion is also reflected in the review of the lessons from the 'place pilots' under a UK governmentsupported initiative known as Total Place, where 'future leaders will not only be people who can work across organisations on behalf of their places, but people who engage effectively with peers, communities, the third sector and with local democratic representatives. They might be political leaders, chief executives, and chief constables; equally they might be programme managers, frontline staff or members of the public' (HM Treasury, 2010). The review also recognised that innovative and sustainable approaches to local challenges are dependent on the quality of local leadership. Likewise, Hambleton (2013) and Hambleton \& Howard (2012) argue that lessons from the UK and the Netherlands demonstrate that placebased leadership can lead to social innovation. Moreover, in the Irish context, it has been argued that effective and innovative spatial planning requires place-based leadership (Hambleton, 2014). Finally, Kania et al. (2014, p. 2) have also argued that a shift in mindsets in terms of "who is engaged, how they work together, and how progress 
happens' is also essential to enhancing collective impact (Kania \& Kramer, 2011).

However, as has been seen with LCDCs, different ideas as to which sector should take the lead role, and whose vision of the aspirational future for a place should be followed, can create tensions, particularly as people develop an emotional attachment to a place or places and it shapes their individual and collective identities (Worrall, 2015). From this perspective, intersectoral collaboratives such as LCDCs are 'sites of struggle' (Madden, 2010, p. 183), and such tensions have been recognised in the literature for a number of years (Blomgren Bingham \& O'Leary, 2006; Saz-Carranza \& Ospina 2011; Vangen, 2012; Vangen \& Huxham 2003a, 2003b, 2011; Vangen \& Winchester, 2014). One of the support mechanisms for developing leaders' collective capability (Pickus, 2013) to work through such tensions and find the best approach for the wider place, looking beyond individual, organisation and sectoral concerns, is known as place-based leadership development (Worrall, 2014, 2015). Moreover, Worrall's (2015) Place-Based Leadership Development (P-BLD) framework, which emerged from a comprehensive study of the lived experience of participants (Kempster \& Parry, 2004) from three place-based collaboratives in three distinct English counties, identified the existence of interlinked tensions at the individual level within self, between self and other, between self and organisation/sector, and between self and wider place. Rather than avoiding such tensions, P-BLD deliberately encourages participants to openly explore their different perspectives, thereby surfacing and facilitating an open dialogue on difficult issues. From these zones of uncomfortable debate (ZOUDs) (Hambleton, 2013) emerges a more collaborative and responsive environment, where leaders have the confidence to embrace uncertainty and develop a more adaptive approach to governance which reflects a dynamic and shifting local context (Hatfield-Dodds et al., 2007).

\section{Lessons learnt}

Drawing on the P-BLD framework, our one-day facilitated workshop was designed to pilot some ideas on themes and approaches that might help build understanding of the governance and local strategic leadership role of LCDC participants. Secondly, it was about getting people to develop their confidence as strategic thinkers, going beyond narrow sectoral interests to work towards achieving the best outcomes 
for their locality. Thirdly, it was about developing oneself to become a more effective collaborative leader by being more open to different perspectives, engaging in constructive dialogue, and managing tensions and conflict to build trust. It also provided us with an opportunity to test out the approach as a learning and development vehicle that could be further developed to effectively respond to the outcomes of the ongoing review of LCDCs led by the Department of Rural and Community Development (DRCD) as a means of building collective capability at a local level. As well as drawing on the expertise of the Institute of Public Administration in governance and leadership, the workshop drew on recent applications of the P-BLD framework (Worrall, 2014, 2015) in East Africa and Central America (Worrall \& Kjaerulf, 2017, 2018a, 2018b, 2018c).

The event was held in a central location, away from Dublin, to encourage participation from a geographically diverse group of LCDC participants. The event attracted twenty-nine participants, including senior officers from fourteen LCDCs, elected members, representatives from the community and voluntary sector, and a representative from the DRCD, which oversees and provides support to the LCDCs. Participants were divided into five diverse groups, and the event was interactive. This encouraged structured group work, reflection and dialogue, as well as plenary feedback and discussions as participants were guided through a series of open questions around governance, governance challenges, challenges in the external environment and the challenges of collaboration.

It was clear from group discussions and plenary feedback that there are some common tensions that need to be worked through by LCDCs. Firstly, whilst there was a clear understanding of what good governance should involve in theory (openness, transparency, accountability and working for the common good, and following due process), the groups also identified a number of barriers. These included conflicts of interest; poor management, with pressure on spending rather than effective resource allocation; personal agendas and domination by certain interests; lack of understanding of governance, roles and responsibilities; and also limited capacity. Secondly, in terms of the external environment, participants felt that LCDCs had had little time to bed in or develop a clear identity before taking on the funding allocation role. It was also a concern that there was too much overlap between funding streams, over-regulation and administrative overload, which stopped more strategic developmental work. Thirdly, the most common collaborative challenge is the lack of trust and a high prevalence of mistrust. Such tensions seem to have 
been exacerbated by 'legacy issues' of negative feelings from the reform process, as well as misunderstanding and the lack of clear communication between representatives of different sectors. Fourthly, there was a reported lack of real engagement by some LCDC members, with people unwilling to share or actively participate. Fifthly, the LCDC is often seen as bureaucratic rather than strategic, and rudderless rather than having a clear direction. Finally, participants also reported that they have found some fellow LCDC members resistant to change and often unwilling to consider doing things differently and to listen to other perspectives.

\section{Implications}

The most concerning common challenge identified by the groups was the reported lack of trust within LCDCs. Building trustful relationships, which starts with enhancing mutual understanding, is the number one prerequisite for effective collaboration within the literature as well as in practice (Worrall, 2014, 2015), and has to be the starting point for developing more effective leadership within LCDCs. It is significant that lack of trust also emerged as a core issue from within the pilot P-BLD for Intersectoral Urban Violence Prevention (IUVP) interventions in Kenya, Uganda and Guatemala (Worrall \& Kjaerulf, 2017, 2018a, 2018b, 2018c). From this perspective, whilst very different contexts, it would appear that learning from the P-BLD interventions in the Global South can be used when building collaborative leadership capability within LCDCs in the Irish context. This would suggest that the design, delivery and systematic evaluation of a number of local pilot P-BLD workshops within individual LCDCs could not only start the process of trust-building, and opening up mindsets, but also provide the foundations for a more effective, longer-term intervention.

\section{References}

Azzopardi, J. C. (2014, Winter). Top down has replaced bottom up. Changing Ireland, 48.

Blomgren Bingham, L., \& O’Leary, R. (2006). Conclusion: Parallel play, not collaboration: Missing questions, missing connections. Public Administration Review, 66, 161-7.

Bryson, J. M., Crosby, B. C., \& Bloomberg, L. (2015). Creating public value in practice: Advancing the common good in a multi-sector, shared power, noone-wholly-in-charge world. Boca Raton, Florida: CRC Press. 
Callanan, M. (2018). Local government in the Republic in Ireland. Dublin: Institute of Public Administration.

Chrislip, D. D. (2002). The collaborative leadership fieldbook. San Francisco, CA: Jossey-Bass.

Chrislip, D. D., \& Larson, C. (1994). Collaborative leadership: How citizens and civic leaders can make a difference. San Francisco, CA: Jossey-Bass.

Community Workers' Co-operative. (2003). Submission to the Department of Community, Rural and Gaeltacht Affairs on the Review of the Local and Community Development Programmes. Galway: Community Workers' Cooperative.

Crosby, B. C., \& Bryson, J. M. (2005). Leadership the common good: Tackling public problems in a shared-power world [J-B US Non-Franchise Leadership]. New York: John Wiley and Sons.

Crosby, B. C., \& Bryson, J. M. (2010a). Special issue on public integrative leadership: Multiple turns of the kaleidoscope. The Leadership Quarterly, 21 (2), 205-8.

Crosby, B. C., \& Bryson, J. M. (2010b). Integrative leadership and the creation and maintenance of cross-sector collaborations. The Leadership Quarterly, 21 (2), 211-30.

Crowley, K., \& Head, B. (2017). The enduring challenge of 'wicked problems': Revisiting Rittel and Weber. Policy Sciences, 50 (4), 539-47.

Department of Rural and Community Development. (2015). Policy paper: Our communities: A framework policy for local and community development in Ireland. Dublin: Department of Rural and Community Development.

European Commission. (2010). Europe 2020: A European strategy for smart, sustainable and inclusive growth. Brussels: European Commission.

Forde, C. (2005). Participatory democracy or pseudo-participation? Local government in Ireland. Local Government Studies, 31 (2), 137-48.

Forde, C., O’Byrne, D., O'Connor, R., O'hAdhmaill, F., \& Power, C. (2015). The changing landscape of local community development in Ireland: Policy and practice. Retrieved from https://cora.ucc.ie/handle/10468/2732 [12 December 2018].

Government of Ireland. (2017). Our public service 2020. Dublin: The Stationery Office.

Hambleton, R. (2009). Place-based leadership and public service innovation. Retrieved from http:/www.urbananswers.co.uk/downloads/1Placebased_thinkpiece.pdf [28 January 2019].

Hambleton, R. (2013). Place-based leadership and radical innovation. Retrieved from http://eprints.uwe.ac.uk/21795 [12 December 2018].

Hambleton, R. (2014). Place-based leadership: A new agenda for spatial planning and local governance. Borderlands: The Journal of Spatial Planning in Ireland, 4, 11-32.

Hambleton, R., \& Howard, J. (2012). Public sector innovation and local leadership in the UK and the Netherlands. York: Joseph Rowntree Foundation. 
Hartley, J. (2018). Ten propositions about public leadership. International Journal of Public Leadership, 14 (4), 202-17.

Harvey, B. (2015). Local community development in Ireland - An overview. In C. Forde, D. O'Byrne, R. O'Connor, F. O'hAdhmaill, \& C. Power, The changing landscape of local community development in Ireland: Policy and practice (pp. 3-4). Retrieved from https://cora.ucc.ie/handle/10468/2732 [12 December 2018].

Hatfield-Dodds, S., Nelson, R., \& Cook, D. (2007, February 13-16). Adaptive governance: An introduction, and implications for public policy. Presented at the 51st Annual Conference of the Australian Agricultural and Resource Economics Society, Queenstown, New Zealand.

HM Treasury. (2010). Policy report. Total Place: $A$ whole area approach to public services. London: HM Treasury.

Kania, J., Hanleybrown, F., \& Splanksy Juster, J. (2014). Essential mindset shifts for collective impact. Retrieved from: https:/ssir.org/articles/entry/ essential_mindset_shifts_for_collective_impact [15 January 2016].

Kania, J., \& Kramer, M. (2011). Collective impact. Retrieved from https://ssir.org/articles/entry/collective_impact [15 January 2016].

Kempster, S., \& Parry, K. W. (2004). The lived experience as leadership development. Presented at the 18th Annual Conference of the Australian and New Zealand Academy of Management.

Kozuch, B., \& Sienkiewicz-Malyjurek, K. (2013). Inter-organizational collaboration as a source of innovation in public management. Retrieved from http://www.toknowpress.net/ISBN/978-961-6914-02-4/papers/ML13254.pdf [21 January 2019].

Lloyd, A. (2016). Policy response. How government's Putting People First policy will effectively put socially excluded people last. Retrieved from https://www.therightsplatform.ie/download/pdf/local_government_reform_ paper.pdf?issuusl=ignore [10 January 2019].

Lyons, M. (2007). Place shaping: A shared ambition for the future of local government. Final report. London: The Stationery Office.

Madden, A. (2010). The community leadership and place-shaping roles of English local government: Synergy or tension. Public Policy and Administration, 25 (2), 175-93.

Nijkamp, P., \& Kourtit, K. (2013). The 'New Urban Europe': Global challenges and local responses in the urban century. European Planning Studies, 21 (3), 291-315.

OECD. (2013). Local economic leadership. Paris: OECD.

Office for Public Management. (2009). Leadership of place: Light touch mapping - Report for IDeA, LCLG, NHSII and NPIA. London: Office for Public Management.

Pickus, K. (2013). The critical role of leadership in driving social innovation. Retrieved from https:/www.forbes.com/sites/skollworldforum/2013/12/27/ the-critical-role-of-leadership-in-driving-social-innovation/\#4b02c3052413 [24 January 2019]. 
Powell, F. (2015). Civil society. Active citizenship and democracy in Ireland. In C. Forde, D. O'Byrne, R. O'Connor, F. O'hAdhmaill \& C. Power, The changing landscape of local community development in Ireland: Policy and practice (pp. 3-5). Retrieved from https://cora.ucc.ie/handle/10468/2732 [12 December 2018].

Saz-Carranza, A., \& Ospina, M. (2011). The behavioral dimension of governing interorganizational goal-directed networks - Managing the unity-diversity tension. Journal of Public Administration Research and Theory, 21 (2), 327-65.

Shannon, L. (2018). Local economic development: An overview of the local economic development role of local government in selected jurisdictions [Local Government Research Series, no. 13]. Dublin: Institute of Public Administration.

Sullivan, H. (2001). Modernisation, democratization and community governance. Local Government Studies, 27 (3), 1-24.

Vangen, S. (2012). Understanding, investigating and theorizing interorganizational collaborations: $A$ focus on paradox. Retrieved from http://oro.open.ac.uk/34823/1/Understanding\%20investigating $\% 20$ and $\% 2$ 0theorizing $\% 20$ inter-organizational $\% 20$ collaborations $\% 20-\% 20 \mathrm{~A} \% 20$ focus\%20on\%20paradox.pdf [28 January 2019].

Vangen, S., \& Huxham, C. (2003a). Enacting leadership for collaborative advantage: Dilemmas of ideology and pragmatism in the activities of partnership managers. British Journal of Management, 14, S61-76.

Vangen, S., \& Huxham, C. (2003b). Nurturing collaborative relationships: Building trust in interorganizational collaboration. Journal of Applied Behaviourial Science, 39 (1), 5-31.

Vangen, S., \& Huxham, C. (2011). The tangled web: Unravelling the principle of common goals in collaboration. Journal of Public Administration Research, 22 (4), 731-60.

Vangen, S., \& Winchester, N. (2014). Managing cultural diversity in collaborations: A focus on tensions. Public Management Review, 16 (5), 686-707.

Worrall, R. (2014, September 8). Illuminating the way: Towards an emergent theory of place-based leadership development. Presented at the Doctoral Colloquium, British Academy of Management Conference, Ulster University, Belfast.

Worrall, R. (2015). Illuminating the way: An emergent theory of place-based leadership development. Doctoral Thesis, Anglia Ruskin University. Retrieved from http://arro.anglia.ac.uk/700620/ [26 January 2019].

Worrall, R., \& Kjaerulf, F. (2017, July 13-14). Transforming places, people and minds: The role of place-based leadership development in urban violence prevention. Presented at the 9th Developing Leadership Capacity Conference, Brighton, UK.

Worrall, R., \& Kjaerulf, F. (2018a, April 12-13). Crossing borders? Comparative analysis of applying a place-based leadership development 
framework for building leadership coalition building for intersectoral urban violence prevention in Kenya and Uganda. Presented at the International Research Society for Public Management Conference, University of Edinburgh, UK.

Worrall, R., \& Kjaerulf, F. (2018b). Building collaborative capability between law enforcement and civil society leaders to prevent urban violence. International Journal of Public Health, 63 (8), 969-76.

Worrall, R., \& Kjaerulf, F. (2018c, September 3-5). South-south: Comparative analysis of applying a place-based leadership development framework for leadership coalition building for intersectoral urban violence prevention in Kenya, Uganda and Guatemala. Presented at the Irish Academy of Management Conference, University College Cork, Ireland. 